\title{
Gambaran Hasil Pemeriksaan Sitologi Serviks Wanita Pekerja Seksual Tidak Langsung pada Hotspot Maredan Kecamatan Tenayan Raya Pekanbaru
}

\author{
Wiwit Ade $^{1}$, Sindy Oktaviani2 ${ }^{*}$, Amru Sofian $^{3}$
}

\begin{abstract}
Cervical cancer is a malignancy of the cervix that can be prevented, but the cause of death of women due to cancer. Cervical cancer is the second most frequent cancer in women in the world. Indirect female sex workers have a higher risk of cervical cancer. The aim of this research was to figure out description of cervical smear examination in indirect female sex workers at hotspot Maredan Tenayan Raya Pekanbaru. Population of this experiment were all indirect female sex workers at hotspot Maredan Tenayan Raya Pekanbaru and samples were taken with total sampling method. The result showed that there were 44 people consist $4 \%$ diagnosed with HSIL, $25 \%$ were diagnosed with LSIL, 30\% diagnosed with ASCUS and $41 \%$ with negative for intraepithelial lesion or malignancy (Bacterial vaginosis, Trichomonas vaginalis, Candidiasis presents).
\end{abstract}

Keywords: Cervical smear, Cervical cancer, Indirect Female Sex Worker, Hotspot Maredan

Kanker serviks adalah keganasan dari serviks (leher rahim) yang dapat dicegah namun merupakan penyebab kematian terbanyak wanita yang disebabkan oleh kanker. ${ }^{1}$ Kanker serviks merupakan kanker kedua terbanyak yang diderita oleh wanita di dunia setelah kanker payudara. ${ }^{2}$ Banyak faktor resiko terjadinya kanker serviks antara lain aktivitas seksual sejak usia dibawah 18 tahun, berganti-ganti pasangan seksual, merokok, multiparitas, dan kondisi sosial ekonomi rendah. ${ }^{1,2}$ Infeksi kronis HPV tipe onkogenik merupakan penyebab lesi pra-kanker yang dapat berkembang menjadi kanker serviks dalam waktu 10-20 tahun apabila tidak diterapi. ${ }^{1,3}$

Menurut data dari World Health Organization (WHO) diperkirakan pada tahun 2012 terjadi 530.000 kasus baru dan sekitar 270.000 kematian akibat kanker serviks, yang hampir $85 \%$ terjadi di negara berkembang. ${ }^{2}$ Menurut data dari Centers for Disease Control and Prevention di negara maju seperti Amerika Serikat pada tahun 2011 tercatat 12.109 wanita terdiagnosis kanker serviks dan 4.092 diantaranya mengalami kematian. ${ }^{4}$ Sedangkan di

\footnotetext{
1 Bagian Patologi Anatomi FK Universitas Riau

${ }^{2 *}$ Penulis untuk korespondensi: FK Universitas Riau.

J1. Diponegoro No. 1, Pekanbaru.

Email: sindy.oktaviani@yahoo.com

3 Bagian Fisiologi FK Universitas Riau
}

Indonesia munurut data dari Institut Catalá d' Oncologia (ICO) pada tahun 2012 tercatat 20.928 wanita terdiagnosis kanker serviks dan 9.498 diantaranya mengalami kematian. ${ }^{5}$ Menurut data dari RSUD Arifin Achmad Pekanbaru, pada tahun 2011 tercatat kasus kanker serviks sebesar 19,5\% dari 168 kasus keganasan pada wanita. ${ }^{6}$

Angka kejadian kanker serviks dapat diturunkan dengan cara melakukan tindakan pencegahan, deteksi dini, dan terapi yang adekuat terhadap lesi pra-kanker. ${ }^{1}$ Deteksi dini yang telah rutin dilakukan di negara maju berpengaruh dalam penurunan angka kejadian kanker serviks dalam waktu 30 tahun terakhir. ${ }^{1,4}$ Papsmear merupakan salah satu metode deteksi dini untuk mendeteksi lesi prakanker yang praktis, relatif murah, cepat dikerjakan, terdokumentasi baik, dan mempunyai spesifisitas yang tinggi. ${ }^{1,7}$

Wanita pekerja seksual tidak langsung (WPSTL) adalah wanita yang secara terselubung menukarkan layanan seksual dengan uang atau barang dan mempunyai pekerjaan lain seperti pelayan kafe, pramupijat, dan penyanyi karaoke. ${ }^{8}$ Aktivitas seksual pada usia dibawah 18 tahun, berganti pasangan seksual, dan kebiasaan merokok menjadikan perkerjaan sebagai WPS-TL beresiko tinggi terhadap kanker serviks. ${ }^{8} \mathrm{Hal}$ ini karena pada 
saat usia dibawah 18 tahun sel-sel serviks belum matur sehingga rentan terhadap infeksi HPV yang dapat ditularkan melalui hubungan seksual. ${ }^{9}$ Selain itu berganti-ganti pasangan seksual juga dapat meningkatkan resiko terkena Infeksi Menular Seksual (IMS) seperti terinfeksi HPV. Mikroorganisme penyebab IMS seperti Trichomonas vaginalis, Chlamydia trachomatis, Herpes simplex tipe 2 juga berpotensi untuk meningkatkan resiko kanker serviks. ${ }^{9} 10$ Kebiasaan merokok WPS-TL juga menyebabkan daya tahan sel-sel serviks menurun terhadap infeksi sehingga serviks sangat rentan terinfeksi. ${ }^{9,10}$

Beberapa lokasi (hotspot) prostitusi di Pekanbaru mendapat pendampingan secara berkala oleh Lembaga Swadaya Masyarakat (LSM) Yayasan Utama. Salah satu hotspot yang mandapat pendampingan dari Yayasan Utama adalah hotspot Maredan. Hotspot Maredan berlokasi di daerah lintas timur sumatera. Lokasi hotspot Maredan yang terletak di daerah lintas timur sumatera membuat hotspot Maredan banyak dilalui oleh truk. Banyak supir truk yang melewati daerah itu menjadi pengguna jasa WPS-TL, sehingga hotspot Maredan beresiko tinggi terhadap IMS dan kanker serviks.

Adapun tujuan penelitian ini adalah untuk mengetahui gambaran hasil pemeriksaan sitologi serviks pada WPS-TL di hotspot Maredan Kecamatan Tenayan Raya Pekanbaru, karakteristik WPS-TL berdasarkan usia, pendidikan terakhir, lama bekerja sebagai WPS-TL, jumlah hubungan seksual perminggu, kebiasaan meminta klien memakai kondom, usia koitus pertama, kebiasaan merokok, jumlah paritas dan gambaran sitologi dari pemeriksaan Pap smear.

\section{METODE}

Jenis penelitian yang digunakan adalah penelitian kuantitatif yang bersifat deskriptif. Pada penelitian ini peneliti akan melihat gambaran hasil sitologi serviks WPS-TL pada hotspot Maredan Kecamatan Tenayan Raya Pekanbaru melalui pemeriksaan Pap smear yang dianalisis di Laboratorium Patologi Anatomi Fakultas Kedokteran Universitas Riau.

Populasi pada penelitian ini adalah WPS-TL di hotspot Maredan Kecamatan Tenayan Raya
Pekanbaru. Sampel penelitian ini adalah seluruh populasi penelitian yang memenuhi kriteria inklusi dan eksklusi (total sampling).

Variabel dalam peneltian ini adalah usia, tingkat pendidikan terakhir, usia koitus pertama, lama berkerja sebagai WPS-TL, paritas, merokok, Pap smear, organism present, Atypical Squamous Cells of Undertermined Significance (ASCUS), Low Grade Squamous Intraepithelial Lesion (LSIL), High Grade Squamous Intraepithelial Lesion (HSIL), Squamous Cells Carcinoma (SCC), Atypical Glandular Cells (AGC) dan adenokarsinoma.

\section{HASIL}

\section{Karakteristik Sampel}

Hasil penelitian ini pada 44 sampel didapatkan data karakteristik responden WPS-TL di hotspot Maredan Kecamatan Tenayan Raya Pekanbaru berdasarkan usia, pendidikan terakhir, lama bekerja sebagai WPS-TL, jumlah hubungan seksual perminggu dan rutinitas dalam meminta klien memakai kondom dapat dilihat pada tabel 1 berikut:

Tabel 1 Karakteristik responden berdasarkan usia, tingkat pendidikan, lama menjadi WPSTL, jumlah hubungan seksual perminggu dan rutinitas meminta klien menggunakan kondom.

\begin{tabular}{lcc}
\hline \multicolumn{1}{c}{ Karakteristik } & Jumlah $(\mathrm{n}=44)$ & Persentase \\
\hline Umur WPS-TL & & \\
16-25 tahun & 25 & $57 \%$ \\
$26-35$ tahun & 17 & $39 \%$ \\
$\quad>35$ tahun & 2 & $4 \%$ \\
Pendidikan Terakhir & & \\
$\quad$ Sekolah Dasar & 16 & $36 \%$ \\
$\quad$ Sekolah Menengah Pertama & 18 & $41 \%$ \\
$\quad$ Sekolah Menengah Atas & 10 & $23 \%$ \\
Lama menjadi WPS-TL & & \\
$\quad<1$ tahun & 28 & $64 \%$ \\
$\quad \geq 1$ tahun & 16 & $36 \%$ \\
JumlahHubungan Seksual & & \\
Perminggu & 28 & $64 \%$ \\
$\quad<5$ kali & 16 & $36 \%$ \\
$\quad \geq 5$ kali & & \\
Rutin Meminta Klien & & \\
Menggunakan Kondom & & \\
$\quad$ Ya & 39 & $89 \%$ \\
$\quad$ Tidak & 5 & $11 \%$ \\
\hline
\end{tabular}


Data penelitian ini menunjukkan sebagian besar WPS-TL dengan umur 15-25 tahun (57\%) dan sebagian besar WPS-TL memiliki pendidikan terakhir SMP (41\%). Mayoritas responden telah bekerja sebagai WPS-TL selama $<1$ tahun $(64 \%)$ dan sebagian besar WPS-TL memiliki jumlah hubungan seksual<5 kali perminggu $(64 \%)$.
Mayoritas WPS-TL mengaku rutin meminta kliennya menggunakan kondom (89\%).

\section{Karakteristik Responden Berdasarkan Usia Koitus Pertama}

Data karakteristik WPS-TL berdasarkan usia saat koitus pertama dapat dilihat pada tabel 2 .

Tabel 2 Karakteristik responden WPS-TL berdasarkan usia koitus pertama

\begin{tabular}{lccc}
\hline & $\begin{array}{c}\text { Usia } \\
\text { (Tahun) }\end{array}$ & $\begin{array}{c}\text { Jumlah } \\
(\mathrm{n}=44)\end{array}$ & Persentase \\
\hline$<18$ & & 30 & $68 \%$ \\
$\geq 18$ & 14 & $32 \%$ \\
\hline Jumlah & 44 & $100 \%$ \\
\hline
\end{tabular}

Dari penelitian didapatkan data sebagian besar WPS-TL melakukan koitus pertama pada usia <18 tahun (68\%), hanya sebagian kecil WPS-TL yang melakukan koitus pertama pada usia $\geq 18$ tahun $(32 \%)$.

\section{Karakteristik responden berdasarkan kebiasaan merokok}

Kebiasaan merokok, jumlah rokok perhari dan lama kebiasaan merokok yang dimiliki WPS-TL di hotspot Maredan Kecamatan Tenayan Raya Pekanbaru dapat dilihat pada tabel 3,4 dan 5berikut:

Tabel 3 Karakteristik responden berdasarkan kebiasaan merokok

\begin{tabular}{lcc}
\hline Kebiasaan Merokok & $\begin{array}{c}\text { Jumlah } \\
(\mathrm{n}=44)\end{array}$ & Persentase \\
\hline Tidak Merokok & 7 & $16 \%$ \\
Merokok & 37 & $84 \%$ \\
\hline Jumlah & 44 & $100 \%$ \\
\hline
\end{tabular}

Data penelitian ini menunjukkan sebagian besar WPS-TLadalah perokok aktif (84\%) sedangkan WPS-TL yang tidak merokok dianggap sebagai perokok pasif karena melalui pengamatan lapangan bau rokok sangat menyengat di setiap ruangan.

Tabel 4 Karakteristik responden berdasarkan jumlah rokok perharinya

\begin{tabular}{lcc}
\hline \multicolumn{1}{c}{ Jumlah batang rokok } & $\begin{array}{c}\text { Jumlah } \\
(\mathrm{n}=37)\end{array}$ & Persentase \\
\hline$<10$ batang rokok & 11 & $30 \%$ \\
$10-20$ batang rokok & 5 & $13 \%$ \\
$>20$ batang rokok & 21 & $57 \%$ \\
\hline Jumlah & 37 & $100 \%$ \\
\hline
\end{tabular}

Dari penelitian ini didapatkan bahwa mayoritas dari WPS-TL merupakan perokok berat, mereka dapat menghabiskan $>20$ batang rokok sehari $(57 \%)$. 
Tabel 5. Karakteristik responden berdasarkan lama kebiasaan merokok

\begin{tabular}{|c|c|c|}
\hline Lama Kebiasaan Merokok & $\begin{array}{c}\text { Jumlah } \\
(\mathrm{n}=37)\end{array}$ & Persentase \\
\hline$<5$ tahun & 17 & $46 \%$ \\
\hline$\geq 5$ tahun & 20 & $54 \%$ \\
\hline Jumlah & 37 & $100 \%$ \\
\hline
\end{tabular}

Data di atas menunjukkan 54\% WPS-TL telah merokok selama $\geq 5$ tahun, hal ini berarti mayoritas WPS-TL memulai kebiasaan merokok sebelum berkerja sebagai WPS-TL.

\section{Karakteristik Responden Berdasarkan Jumlah Paritas}

Riwayat paritas merupakan salah satu faktor risiko terhadap kanker serviks, dalam penelitian ini didapatkan data karakteristik WPS-TL berdasarkan jumlah paritas yang dapat dilihat pada tabel 6 .

Tabel 6 Karakteristik responden berdasarkan jumlah paritas

\begin{tabular}{|c|c|c|}
\hline Status Paritas & $\begin{array}{c}\text { Jumlah } \\
(\mathrm{n}=44)\end{array}$ & Persentase \\
\hline Nulipara & 17 & $39 \%$ \\
\hline$<3$ kali & 23 & $52 \%$ \\
\hline$\geq 3$ kali & 4 & $9 \%$ \\
\hline Jumlah & 44 & $100 \%$ \\
\hline
\end{tabular}

Jumlah responden dalam penelitian ini yang pernah melakukan persalinan $<3$ kali adalah sebesar $52 \%$. Dari informasi yang didapat seluruh WPS-TL tidak pernah melakukan abortus dan semua persalinan dilakukan secara pervaginam.

\section{Hasil Pemeriksaan Sitologi Serviks Berdasarkan Kriteria Bethesda 2001}

Hasil pemeriksaan sitologi serviks WPS-TL di hotspotMaredan Kecamatan Tenayan Raya Pekanbaru berdasarkan sistem Bethesda 2001dapat dilihat pada tabel 7.

Tabel 7 Karakteristik hasil pemeriksaan sitologi responden berdasarkan sistem Bethesda 2001

\begin{tabular}{lcc}
\hline \multicolumn{1}{c}{ Hasil Pemeriksaan Sitologi } & $\begin{array}{c}\text { Jumlah } \\
(\mathrm{n}=44)\end{array}$ & Presentase \\
\hline $\begin{array}{l}\text { Tidak ditemukan lesi intraepitel atau keganasan } \\
\text { (ditemukan organisme lain) }\end{array}$ & & \\
Bacterial vaginosis & 12 & $28 \%$ \\
Trichomonas vaginalis & 4 & $9 \%$ \\
Candidiasis & 2 & $4 \%$ \\
Ditemukan kelainan sel epithelial & & \\
ASCUS & 13 & $30 \%$ \\
LSIL & 11 & $25 \%$ \\
HSIL & 2 & $4 \%$ \\
\hline Jumlah & 44 & $100 \%$ \\
\hline
\end{tabular}


Berdasarkan Tabel 4.5 didapatkan bahwa WPS-TL di hotspot Maredan Kecamatan Tenayan Raya Pekanbarudidapatkan responden dengan hasil tidak ditemukan lesi intraepitelial sebanyak 18 orang (41\%) tetapi terdapat infeksi organisme yaitu: 12 orang (28\%)dengan infeksi Bacterial vaginnosis, 4 orang (9\%) Trichomoniasis vaginalis dan 2 orang (4\%) kandidiasis. Pada penelitian juga ditemukan hasil lesi intraepitelial sebanyak 26 orang (59\%) yaitu: ASCUS sebanyak 13 orang (30\%), LSIL sebanyak 11 orang $(25 \%)$ dan HSIL sebanyak 2 orang $(4 \%)$.

\section{PEMBAHASAN}

Penelitian ini dilakukan pada 44 orang WPSTL yang ada di hotspot Maredan Kecamatan Tenayan Raya Pekanbaru dengan distribusi kelompok umur WPS-TL 16-25 tahun sebanyak 25 orang $(57 \%)$. Hal ini didukung oleh penelitian Budiman di hotspot Jalan Tuanku Tambusai Pekanbaru pada tahun 2013 didapatkan 45\% responden berusia 18-25 tahun. ${ }^{6}$ Penelitian yang dilakukan oleh Kurniawan di lokalisasi Dolly Surabaya pada tahun 2008 didapatkan 61\% WPS berusia 21-25 tahun. ${ }^{11}$ Penelitian yang dilakukan oleh International Organization for Migration (IOM) di Kenya pada tahun 2011 didapatkan 52\% WPS berusia 20-29 tahun. ${ }^{12} \mathrm{Hal}$ ini berbeda dengan penelitian Smith dan Kingston di Inggris pada tahun 2015 dimana didapatkan 54\% WPS berusia 25-34 tahun. ${ }^{13}$ Penelitian Beduk di Turki pada tahun 2012 didapatkan 53\% WPS berusia diatas 40 tahun. ${ }^{14}$

Perbedaan usia ini disebabkan karena WPS di Inggris dan di Turki merupakan pekerjaan yang dilegalkan dan diatur secara ketat oleh pemerintah. ${ }^{13,14}$ Sementara pada penelitian ini WPS merupakan pekerjaan ilegal sehingga tidak memiliki batasan usia tertentu dan tidak ada pengawasan langsung dari pemerintah. Usia menjadi faktor risiko penting dalam penyakit kanker serviks, sebab menurut teori kejadian tertinggi kanker serviks terjadi pada wanita berusia 40 tahun keatas. ${ }^{5,7}$ Menurut teori wanita yang berusia $>35$ tahun mempunyai risiko 3 kali lebih besar terkena kanker serviks dibandingkan dengan wanita yang berusia $<35$ tahun. ${ }^{15}$

Hampir sebagian besar responden yang ada di hotspot Maredan Kecamatan Tenayan Raya
Pekanbaru memiliki tingkat pendidikan terakhir SMP yaitu sebanyak $41 \%$. Hal yang sama juga ditemui pada penelitian Budiman didapatkan di hotspot Jalan Tuanku Tambusai Pekanbaru 39\% WPS-TL memiliki tingkat pendidikan terakhir SMP. ${ }^{6}$ Penelitian Kurniawan didapatkan di lokalisasi Dolly 52\% WPS memiliki tingkat pendidikan terakhir SMP. ${ }^{11}$ Penelitian Ninik di lokalisasi Gembol Semarang pada tahun 2012 didapatkan 86\% WPS memiliki tingkat pendidikan terakhir SMP. ${ }^{16}$ Namun berbeda dengan peneltian yang dilakukan oleh Dandona di India pada tahun 2006 didapatkan $77 \%$ WPS buta huruf. ${ }^{17}$ Penelitian IOM di Kenya didapatkan $47 \%$ WPS tidak pernah bersekolah. ${ }^{12}$ Perbedaan tingkat pendidikan ini disebabkan karena di India wanita dari kalangan sosial ekonomi rendah hanya dipersiapkan untuk mengurus pekerjaan rumah tangga sehingga mereka tidak mendapatkan pendidikan yang baik. ${ }^{17}$ Mayoritas WPS di Kenya adalah imigran yang memiliki tingkat ekonomi yang rendah sehingga kebanyakan tidak mampu untuk bersekolah. ${ }^{12}$ Sementara dalam penelitian ini responden mendapatkan kesempatan untuk bersekolah, karena alasan ekonomi mayoritas responden hanya dapat bersekolah hingga tingkat SMP. Tingkat pendidikan terakhir menjadi faktor penting dalam penyakit kanker serviks, menurut teori tingkat pendidikan yang rendah menyebabkan pengetahuan tentang kanker serviks dan pencegahannya juga rendah. ${ }^{18}$

Mayoritas responden yang ada di hotspot Maredan Kecamatan Tenayan Raya Pekanbaru merupakan WPS-TL yang belum lama bekerja sebagai WPS dimana sebanyak $64 \%$ baru bekerja sebagai WPS selama $<1$ tahun. Hal ini didukung oleh penelitian Budiman didapatkan di hotspot Jalan Tuanku Tambusai Pekanbaru 71\% WPS-TL baru berkerja selama 1-6 bulan. ${ }^{6}$ Penelitian Kurniawan didapatkan 64\% WPS baru bekerja selama <1 tahun. ${ }^{11}$ Penelitian Jia di Cina pada tahun 2015 didapatkan $78 \%$ WPS baru bekerja selama $<1$ tahun. ${ }^{19} \mathrm{Hal}$ ini bertolak belakang dengan penelitian Patel di India pada tahun 2013 didapatkan 50\% responden telah bekerja lebih dari 10 tahun sebagai WPS. ${ }^{20}$ Penelitian Bui di Phnom Penh pada tahun 2013 didapatkan 65\% WPS telah bekerja $>1$ tahun sebagai WPS. ${ }^{21}$ Penelitian Beduk di Turki didapatkan 77\% WPS telah bekerja sebagai WPS selama 3-20 tahun. ${ }^{14}$ Perbedaan ini dapat disebabkan 
karena rumah border di India, Phnom Phen dan Turki telah mempekerjakan WPS sejak usia belasan tahun sehingga waktu mereka bekerja sebagai WPS menjadi semakin lama. ${ }^{14,20,21}$ Sementara dalam penelitian ini responden memiliki tingkat mobilitas yang tinggi sehingga wanita yang telah lama bekerja sebagai WPS cenderung berpindah ke hotspot yang lain. Lama bekerja sebagai WPS menjadi faktor penting karena makin lama masa kerja seorang WPS, makin besar kemungkinan ia telah terinfeksi HPV dan mengalami displasia serviks ..$^{10,18}$

Sebagian besar responden memiliki jumlah hubungan seksual perminggu $<5$ kali yakni sebesar $64 \%$. Hal yang sama juga ditemui pada penelitian Hernandez di Vietnam pada tahun 2008 didapatkan 36\% WPS memiliki jumlah hubungan seksual 1-4 kali perminggu. ${ }^{22}$ Namun hal ini berbeda dengan penelitian Budiman hotspot Jalan Tuanku Tambusai Pekanbaru didapatkan 48\% WPS-TL melakukan hubungan seksual 30-35 kali perminggu. ${ }^{6}$ Penelitian Kurniawan pada WPS-L di lokalisasi Dolly didapatkan 43\% WPS melakukan hubungan seksual 21-35 kali perminggu. ${ }^{11}$ Perbedaan ini dapat disebabkan karena pada penelitian Budiman dan Kurniawan lokasi penelitian terletak di tengah kota. ${ }^{6,11}$ Sementara pada penelitian ini lokasi penelitian terletak diperbatasan kota Pekanbaru dan kabupaten Siak. Jumlah hubungan seksual menjadi faktor penting karena wanita yang memiliki lebih dari 5 pasangan seksual mempunyai resiko terkena kanker serviks 10 kali lebih besar dibanding wanita yang memiliki 1 pasangan seksual. ${ }^{10,18}$

Mayoritas responden tidak memiliki kebiasaan meminta klien menggunakan kondom (82\%). Hal ini didukung oleh penelitian penelitian Pogetto di Brazil pada tahun 2012 didapatkan 99\% WPS mengatakan rutin meminta klien mereka menggunakan kondom saat melakukan hubungan seksual. ${ }^{23}$ Penelitian Bui di Phnom Penh didapatkan $65 \%$ WPS rutin meminta klien untuk menggunakan kondom saat berhubungan seksual. ${ }^{21}$ Sebaliknya, pada penelitian Budiman di hotspot Jalan Tuanku Tambusai Pekanbaru didapatkan 77\% WPS-TL tidak meminta klien menggunakan kondom saat melakukan hubungan seksual. ${ }^{6}$ Penelitian Hernandez di Vietnam didapatkan 84\% WPS tidak meminta klien menggunakan kondom saat melakukan hubungan seksual. ${ }^{22}$ Perbedaan ini dapat disebabkan karena responden pada penelitian
Budiman dan Hernandez memiliki pengetahuan yang kurang baik tentang kesehatan reproduksi dan kebanyakan klien yang tidak menginginkan menggunakan kondom saat berhubungan seksual. ${ }^{6,22}$ Sementara pada penelitian ini responden telah mendapatkan sosialisasi mengenai kesehatan reproduksi oleh LSM dan Dinas Kesehatan Kota Pekanbaru dan di hotspot Maredan ada peraturan yang mewajibkan seluruh klien untuk memakai kondom saat berhubungan seksual. Kebiasaan menggunakan kondom menjadi faktor penting karena menurut teori kondom dapat memberikan perlindungan terhadap IMS. ${ }^{24}$

Faktor-faktor karakteristik sampel yang sudah dibahas diatas memiliki hubungan langsung dengan risiko WPS-TL terhadap kanker serviks, namun faktor risiko tersebut melekat hanya pada wanita yang bekerja sebagai WPS.

Berdasarkan hasil penelitian, mayoritas responden melakukan koitus pertama pada usia $<18$ tahun yakni sebesar 68\% dan $32 \%$ responden yang melakukan koitus pertama pada usia $\geq 18$ tahun. Hal yang sama juga ditemui pada penelitian Beduk di Turki pada didapatkan 85\% WPS melakukan koitus pertama pada usia 9-19 tahun. ${ }^{14}$ Penelitian Patel di India didapatkan 56\% WPS melakukan koitus pertama kali pada usia 15-19 tahun. ${ }^{20} \mathrm{Hal}$ yang berbeda didapatkan pada peneltian Jia di Cina 50\% WPS melakukan koitus pada usia $>20$ tahun. ${ }^{19}$ Perbedaan ini disebabkan karena tingkat pengetahuan mengenai kesehatan reproduksi WPS di Cina cukup baik. ${ }^{19}$ Usia koitus pertama menjadi faktor penting karena menurut teori, wanita yang aktif melakukan hubungan seksual pada usia dibawah 18 tahun memiliki resiko lebih tinggi terkena kanker serviks. ${ }^{1,29}$ Hal ini dikarenakan sel epitel serviks yang masih belum matur lebih rentan terhadap infeksi. ${ }^{9}$

Berdasarkan hasil penelitian, sebagian besar responden adalah perokok aktif yakni sebesar $84 \%$, sementara $16 \%$ lainnya tidak merokok. Hal ini didukung oleh penelitian Budiman di hotspot Jalan Tuanku Tambusai Pekanbaru didapatkan 87\% WPSTL adalah perokok aktif. ${ }^{6}$ Penelitian Pogetto di Brazil didapatkan 70\% WPS adalah perokok aktif. ${ }^{23}$ Penelitian Ersan di Turki pada tahun 2013 didapatkan 62\% WPS adalah perokok aktif. ${ }^{25} \mathrm{Hal}$ yang berbeda didapatkan pada penelitian Tideman di Sydney pada tahun 2003 dimana hanya 56\% 
WPS-L di Sydney merupakan perokok aktif. ${ }^{26}$ Penelitian Odukoya di Nigeria pada tahun 2013 didaptkan $72 \%$ WPS tidak pernah merokok. ${ }^{27}$ Perbedaan ini disebabkan karena peraturan larangan merokok pada lokasi penelitian tersebut. Peraturan tentang larangan merokok di ruang publik, larangan menjual rokok pada anak dibawah umur dan harga rokok yang tinggi dapat mengurangi hampir 50\% perokok aktif di Australia dalam kurun waktu 19802007. ${ }^{26}$ Mayoritas WPS di Nigeria mengkonsumsi alkohol dan hanya sebagian kecil yang merokok. ${ }^{27}$ Merokok merupakan faktor penting karena menurut teori, wanita yang merokok memiliki resiko 2 kali lebih besar dapat terkena kanker serviks dibandingkan dengan wanita yang tidak merokok.Pada lendir serviks wanita perokok ditemukan zat benzyrene dari asap rokok yang menyebabkan sel-sel Langerhans yang ada pada serviks tidak berfungsi baik, sehingga daya tahan serviks terhadap infeksi menurun. Selain itu nikotin yang ada didalam rokok bersifat ko-karsinogen yang dapat mendorong displasia menjadi kanker serviks. ${ }^{10,13}$

Pada penelitian ini didapatkan responden perokok aktif mayoritas menghabiskan $>20$ batang rokok perhari yakni sebesar $57 \%$. Hal yang sama juga didapatkan pada penelitian Pogetto di Brazil $71 \%$ WPS perokok menghabiskan hingga 25 batang rokok perhari. ${ }^{47}$ Hal yang berbeda didapatkan pada penelitian Budiman di hotspot Jalan Tuanku Tambusai Pekanbarusebesar 85\% WPS-TL perokok menghabiskan $<15$ batang rokok perhari. ${ }^{6}$ Penelitian Kurniawan di lokalisasi Dolly didapatkan $84 \%$ WPS-L perokok menghabiskan $<20$ batang rokok perhari. ${ }^{36}$ Perbedaan ini disebabkan karena faktor adiksi nikotin pada perokok dimana pada penelitian Budiman didapatkan 52\% responden telah merokok selama 5-10 tahun dan menyebabkan peningkatan jumlah konsumsi rokok perhari. ${ }^{6}$

Mayoritas responden dalam penelitian ini mengaku telah merokok selama $\geq 5$ tahun yakni sebesar 54\%.Hal yang sama didapatkan pada penelitian Budiman di hotspot Jalan Tuanku Tambusai Pekanbaru dimana 67\% WPS-TL telah merokok sejak $>5$ tahun. ${ }^{6}$ Penelitian Daecon di Inggris pada tahun 2000 didapatkan $74 \%$ WPS telah merokok $>9$ tahun. ${ }^{28}$ Lama merokok menjadi faktor penting karena rokok dapat menurunkan status imunitas serviks dan nikotin yang ada didalam rokok merupakan suatu zat yang dapat mendorong displasia menjadi kanker serviks. ${ }^{10,29}$

Berdasarkan hasil penelitian, mayoritas responden memiliki riwayat persalinan pervaginam sebanyak <3 kali yakni sebesar 52\%. Hal ini didukung oleh penelitian Budiman di hotspot Jalan Tuanku Tambusai Pekanbaru dimana 58\% respondennya pernah melahirkan 1-2 kali. ${ }^{6}$ Penelitian Kurniawan di Dolly didapatkan 57\% WPS memiliki riwayat persalinan sebanyak 1-2 kali. ${ }^{11}$ Hal yang berbeda tampak pada penelitian Daecon di Inggris didapatkan 69\% WPS memiliki riwayat persalinan sebanyak 1-3 kali. ${ }^{28}$ Menurut teori riwayat multiparitas merupakan salah satu faktor resiko kanker serviks. Wanita yang mempunyai anak $>7$ memiliki resiko 2 kali lipat lebih tinggi dapat terkena kanker serviks dibandingkan wanita yang mempunyai 1 anak. ${ }^{9,10}$ Hal ini berkaitan dengan selama kehamilan terjadi perubahan hormon, penurunan sistem imunitas, dan trauma yang terjadi pada serviks saat proses persalinan sehingga rentan terhadap infeksi HPV. ${ }^{9}$

Hasil akhir pemeriksaan sitologi serviks 44 responden dengan menggunakan sistem pelaporan Bethesda didapatkan responden dengan hasil tidak ditemukan lesi intraepitelial atau keganasan (ditemukan Bacterial vaginosis, Trichomonas vaginalis dan kandidiasis) sebanyak 18 orang (41\%). Sementara itu sebanyak 26 WPS-TL (59\%) terdeteksi menderita kelainan sel epitelial yakni ASCUS, LSIL dan HSIL. Hal ini didukung oleh penelitian Budiman di hotspot Jalan Tuanku Tambusai Pekanbaru didapatkan 45\% WPS-TL memiliki kelainan sel epithelial. ${ }^{6}$ Penelitian Jia di Cina pada didapatkan 53\% WPS memiliki kelainan sel epithelial. ${ }^{19}$ Perbedaan lainnya juga tampak pada penelitian Tideman di Sydney didapatkan hanya $17 \%$ WPS yang mengalami kelainan sel epitelial. ${ }^{26}$ Hal ini disebabkan oleh regulasi prostitusi pada masing-masing negara, karenadi Australia prostitusi menjadi pekerjaan legal yang diatur secara ketat oleh hukum sehingga WPS mendapatkan pengawasan kesehatan oleh pemerintah secara berkelanjutan. ${ }^{6,26}$

\section{KESIMPULAN}

Berdasarkan hasil penelitian didapatkan mayoritas WPS-TL berusia 16-25 tahun, mayoritas memiliki tingkat pendidikan terakhir SMP, 
mayoritas telah berkerja sebagai WPS-TL selama $<1$ tahun. Mayoritas memiliki jumlah hubungan seksual perminggu $<5$ kali perminggu. WPS-TL rutin meminta klien menggunakan Kondom. Mayoritas WPS-TL saat melakukan koitus pertama berusia <18 tahun. Mayoritas WPS-TL memiliki kebiasaan merokok yakni. Jumlah rokok perhari yang dihisap WPS-TL terbanyak adalah $>20$ batang. Mayoritas WPS-TL memiliki kebiasaan merokok selama $\geq 5$ tahun. Mayoritas WPS-TL memiliki status paritas telah melahirkan $<3$ kali. Pemeriksaan sitologi serviks dilakukan pada 44 WPS-TL, didapatkan 59\% lesi intraepitelial. Masing-masing $30 \%$ ASCUS, $25 \%$ LSIL, $4 \%$ HSIL. Pada penelitian ini juga didapatkan $41 \%$ dengan infeksi organisme yaitu: $28 \%$ dengan infeksi Bacterial vaginnosis, $9 \%$ Trichomoniasis vaginalis dan $4 \%$ kandidiasis.

\section{DAFTAR PUSTAKA}

1. World Health Organization. Comprehensive cervical cancer control. A guide to essential practice.2nd ed.Australia : WHO Publication; 2014.

2. World Health Organization. Human papillomavirus and cervical cancer. Switzerland [Internet]. 2014. [cited 2015 Feb10]. Available from : http://www.who.int/mediacentre/ factsheets/fs380/en/

3. Crosbie EJ, Einstein MH, Franceschi S, Kitchener HC. Human papillomavirus and cervical cancer. Lancet [Internet]. 2013. [cited 2015 Feb 10]. Available from: http:// www.ncbi.nlm.nih.gov/pubmed/23618600

4. Centers for Disease Control and Prevention. Cervical cancer statistic. Gynecology cancers. United States[Internet]. 2014. [cited 2015 Feb 10]. Available from: http://www.cdc.gov/cancer/ cervical/statistics/

5. ICO Information Centre on HPV and Cancer. Human papillomavirus and related cancers in world. Summary report. Spain: ICO Publication; 2014.

6. Budiman KA. Gambaran pemeriksaan sitologi serviks wanita pekerja seksual tidak langsung pada hotspot jalan tuanku tambusai kecamatan sukajadi pekanbaru [tesis]. Pekanbaru. Universitas Riau; 2013.
7. Broadman $\mathrm{CH}$. Cervical cancer. United States [Internet]. 2014. [cited 2015 March 23]. Available from: http://emedicine.medscape.com/ article/253513-overview\#aw2aab6b2b4

8. Lokollo FY.Studi kasus perilaku wanita pekerja seksual tidak langsung dalam pencegahan IMS, hiv dan aids di pub\& karaoke, café, dan diskotek di kota semarang [tesis]. Semarang:Universitas Diponegoro; 2009.

9. Harvard School of Public Health. Disease risk index. Cervical cancer. United States [Internet]. 2008. [cited 2015 Feb 10]. Available from: http:/ /www.diseaseriskindex.harvard.edu/update/ hccpquiz.pl?lang=english \&func $=$ show $\&$ quiz $=$ cervical\&page=risk_list

10.Cancer research UK. Cervical cancer risk and causes. England [Internet]. 2014. [cited $2015 \mathrm{Feb}$ 10]. Available from: http:// www.cancerresearchuk.org/about-cancer/type/ cervical-cancer/about/cervical-cancer-risks-andcauses

11. Kurniawan B. Hubungan tingkat pengetahuan dengan partisipasi pada pemeriksaaan pap smear pada wanita pekerja seks komersial. Jurnal Kedokteran Brawijaya. 2008;26(3):3.

12.International Organization for Migration. Integrated biological and behavioral surveillance survey among migrant female sex in nairobi, kenya. Summery report. Kenya: IOM Publication; 2011

13. Smith N, Kingston S. Policy-relevant report: statistic on sex work in the uk. United Kingdom: University of Birmingham; 2015.

14. Beduk T, Unclu H, Duyan V. AIDS knowledge and risky sexual behaviors among female sex workers in turkey. Turk J Med Sci. 2011; 41(3): 521-531.

15.Andrijono. Kanker serviks. Jakarta: Divisi Onkologi Departemen Obstetri Ginekologi Fakultas Kedokteran Indonesia; 2007.

16.Ninik, Nugraha P, Riyanti E. Perilaku wanita pekerja seks dalam pencegahan infaksi menular seksual (studi kualitatif pada anak asuh di lokalisasi gambol, sukosari, bawen, kabupaten semarang). Media Kesehatan Masyarakat Indonesia. 2012;11(1):3. 
17.Dandona R, Dandina L, Kumar GA, Gutierrez JP, McPherson S, Samuels F, et al. Demography and sex work characteristic of female sex workers in india. United Kingdom: BMC International Health and Human Rights; 2006

18. University of Maryland Medical Center. Cervical cancer. United States [Internet]. 2013. [cited 2015 March 23]. Available from: http:// umm.edu/health/medical/reports/articles/ cervical-cancer.

19.Jia H. Human papillomavirus infection and cervical dysplasia in female sex workers in northeast china: an observational study. BMC Public Health. 2015;15:695.

20.Patel V, Puwar B, Vyas S. Sex work characteristic of female sex workers (fsws) in ahmedabad city. IJSR.2013;2(2):2.

21.Bui TC, Markham CM, Ly TH, Beasley RP, Ross MW. Condom negotiation and use among female sex workers in phnom penh, Cambodia. AIDS Behav. 2013; 17(2): 612-622.

22.Hernandez BY. Cervical human papillomavirus infection among female sex workers in southern vietnam. Infectious agents and cancer.2008;3:7.

23.Pogetto MR. Characteristic of a population of sex workers and their association with the presence of sexually transmitted disease. USP. 2012;46(4):5.
24.Saonere JA. Awareness screening programme reduces the risk of cervical cancer in women. African Journal of Pharmacy and Pharmacology. 2010;4(6):314-323.

25.Ersan G, Kose S, Senger SS, Gunes H, Sehirali S, Gurbuz I. The prevalence and risk factors of human papillomavirus in female sex workers. EAMJ. 2013; 45: 16-20.

26.Tiderman RL. Cervical human papillomavirus infections in commercial sex workers-risk factors and behaviours. Int J STD AIDS. 2003; 14(12):840-7.

27. Odukoya OO, Sekoni AO, Onajole AT, Upadhyay RP. Alcohol consumtion and cigarette smoking pattern among brothel-based female sex workers in teo local government areas in lagos state nigeria. African Health Sciences. 2013; 13.

28.Daecon JM. Sexual behavior and smoking as determinants of cervical hpv infection and of cin3 among those infected: a case-control study nested within the menchester cohort. British Journal of Cancer. 2000; 88(1): 1565-1572

29. Haverkos HW. Multifactorial etiology of cervical cancer: hypothesis. United States [Internet]. 2005. [cited 2015 March 23]. Avalable from: http://www.medscape.com/viewarticle/515768 